\title{
Sustainable Green Charcoal Briquette from Food Waste via Microwave Pyrolysis Technique: Influence of Type and Concentration of Binders on Chemical and Physical Characteristics
}

\author{
Siti Shawalliah Idris ${ }^{1,2^{*}}$, Muhammad Izwadi Zailan¹, Nabihah Azron ${ }^{1}$, Norazah Abd \\ Rahman ${ }^{1}$
}

${ }^{1}$ Faculty of Chemical Engineering, Universiti Teknologi MARA, Shah Alam, Selangor, Malaysia

${ }^{2}$ Renewable Energy and Advance Chemical Technology (REACT) Research Group, Faculty of Chemical Engineering, Universiti Teknologi MARA, Shah Alam, Selangor Darul Ehsan, Malaysia

\begin{abstract}
Turning the food waste into a fuel source such as charcoal briquette was one of the alternatives in managing the food wastes disposal. In this present work, food waste was converted into charcoal by microwave irradiation technique. Application of binders such as potato starch and carboxymethyl cellulose (CMC) at ratios of $5 \%, 10 \%$ and $15 \%$ for briquetting purpose were investigated in terms of its chemical and physical characteristics. Result showed that the briquette formed using the starch as the binder performed better in combustion quality than that of carboxymethylcellulose (CMC). A good quality of charcoal briquette has capability to withstand impact during packaging, handling, and transportation. Standard physical characteristic that was tested for briquette includes moisture content, compressive strength, and impact resistance. Calorific value of briquette was studied to analyse energy content in the briquette. The study showed that food waste charcoal has calorific value comparable to that of the commercial charcoal. However, the addition of binders showed some reduction in the energy content, with more reduction when CMC is added. In terms of combustion characteristic, the addition of binders does not alter the combustion profile in comparison to the raw food waste charcoal's profile. The ignition and burnout temperatures of the food waste charcoal briquette showed a better performance with and without binders as compared to the commercial charcoal. In terms of physical characteristics, CMC has showed as an excellent binder with highest shatter index value. Overall, in terms of chemical properties, addition of $10 \%$ starch showed a better performance, while addition of $10 \%$ CMC showed a better performance in terms of physical characteristics. This finding is beneficial for briquette industry in the development of green product using biomass, but further research is essential before production of briquette take place.
\end{abstract}

Keywords: Food wastes charcoal briquette; microwave pyrolysis technique; waste-to-wealth; CMC; starch.

Article History: Received: 26 ${ }^{\text {th }}$ Sept 2020; Revised: $5^{\text {th }}$ January 2021; Accepted: $3^{\text {rd }}$ February 2021; Available online: $17^{\text {th }}$ February 2021

How to Cite This Article: Idris, S.S., Zailan, M.I., Azron, N., Rahman, N.A. (2021) Sustainable green charcoal briquette from food waste via microwave pyrolysis technique: Influence of type and concentration of binders on chemical and physical characteristics. International Journal of Renewable Energy Development, 10(3), 425-433.

https://doi.org/10.14710/ijred.2021.33101

\section{Introduction}

Food is essential to human being yet is a nuisance if it is improperly managed. In 2013 , about $44.50 \%$ of the municipal solid waste generated in Malaysia was contributed by food waste, followed by $13.20 \%$ and $12.10 \%$ contributed by plastic and diapers wastes, respectively. In the recent source, the food waste increased by $15-20 \%$ during festive seasons (SW Corp.). These wastes were traditionally managed by the authority through landfilling, which counts for about 10 million tonne/annum, posing various environmental issues (Friege et al., 2010). It is important to note that Malaysia composed of citizen of diverse culture, thus, the nature of food intake and its waste to an extent are culturally oriented. In general, the wastes composition of food waste, in general, can be categorised into classes such as carbohydrate (e.g. rice, bread, noodles), vegetables (cellulosic), and meats (e.g. poultry, meat, and fish). Because the food is majority of oily nature, thus, making it very difficult to handle, unlike the food wastes from other countries such as the western and eastern part of the world. The categories that were mentioned earlier, naturally contains energy value, however, it was lowered down by the presence of water ( ca. $70-80$ wt.\%).

Several technologies have emerged in solving these problems, which involve the use of bacteria for bio-gas generation and composting, whose processing rate is slow. On the other hand, thermochemical conversion such as combustion and incineration, is limited because of the

\footnotetext{
* Corresponding author: shawal075@uitm.edu.my
} 
Citation: Idris, S.S., Zailan, M.I., Azron, N., Rahman, N.A. (2021) Sustainable green charcoal briquette from food waste via microwave pyrolysis technique: Influence of type and concentration of binders on chemical and physical characteristics. Int. Journal of Renewable Energy Development, 10(3), 425-433, doi: 10.14710/ijred.2021.33101

$\mathrm{P}$ a g e $\mid 426$

nature of food waste that contains high moisture, thus impose technological problem, which eventually lead to traditional disposal method of landfilling. Landfilling consumes large spaces and pose environmental problem as the degradation of the wastes release leachate and greenhouse gases emission.

Pyrolysis is another thermal conversion technique that is suitable to convert waste to useful products. The use of radiative heating source as opposed to the conventional heating technique i.e. conductive heating has been proposed using microwave. The electromagnetic wave of microwave is normally at the frequency of $2450 \mathrm{MHz}$ which has the right penetration depth for heating to induce pyrolysis. Microwave pyrolysis was induced from the interaction between the electromagnetic wave that causing the molecular dipoles and charged ions to interact. The molecules oscillate in the is magnetic field, converting the microwave energy into heat, hence inducing pyrolysis condition. Microwave induce heating within the core of the substance through a direct energy conversion (Bu et al., 2016). Its selective heating is of advantageous and is seen as an alternative solution by manipulating 'wet' nature of the food waste through its interaction with microwave energy. Microwave energy is easily absorbed by highly moisture material (receptive by nature) inducing pyrolysis process, hence, converting valuable energy content in the food waste, into solid charcoal, liquid, and gas fractions. These fractions, can be used as fuel directly or through relevant upgrading methods and optimised according to desirable selectivity by manipulating necessary process conditions. In comparison to conventional pyrolysis, microwave irradiation pyrolysis is seen to be a favourable method particularly in dealing with highly moisture samples because of its ability to convert electromagnetic energy into thermal energy rapidly, allowing volumetric heating, and has higher energy efficiency (Antunes et al., 2018; Elkhalifa et al., 2019).

The solid fraction of pyrolysis product (charcoal) is known to have high calorific value due to high fix carbon content. Li et al. (2016) had reviewed on biochar from biomass using microwave pyrolysis technique. It was reported that the biochar produced from this technique is of higher quality, with high surface area and pore volume as compared to that of conventional pyrolysis. The conventional heating causing cracks that leads to fragile biochar due to the convective heating profile and temperature gradients. Foong et al. (2020) reported that the biochar derived from casava stems produced through microwave technique had high heating value ranging from 19 to $20 \mathrm{MJ} / \mathrm{kg}$, which is suitable for fuel application. Although several research appears to investigate on the microwave pyrolysis of food waste, some researcher predried the sample for moisture removal prior to processing in the microwave pyrolysis process (Kadlimatti et al., 2019; Liu et al., 2014). Thus far, Januri et al. (2016) had performed the conversion of food waste using microwave pyrolysis technique without the need to pre-dried, and reported the characteristic of the solid char with and without the presence of absorber at different radiation time.

Charcoal briquette has been one of the main sources of solid fuel particularly in domestic heating application such as for cooking and space heating. Traditionally, charcoal briquette used to be derived from the Mangrove tree (Bakau), undergoing carbonisation, in which the process takes days of heating. Massive deforestation of Mangrove must be prevented to ensure the sustainability of the ecosystem. Recently, the alternative of charcoal briquette has been derived from biomass wastes such as palm kernel shell and woodchip. Charcoal characteristic i.e., brittleness has been a major problem, hence briquetting requires an addition of binders as it could improve the physical characteristics for ease of utilisation by consumers. According to Sotannde, (Sotannde et al., 2010), various techniques can be done in order to briquette the biomass, either with or without binder addition. The material of the binder can help to hold the particles of the charcoal to be strongly together in place. This can ensure the briquette to sufficiently hard enough to hold competently when burned. It is necessary for the material of the binder to be combustible, but the effectiveness of a non-combustible binder is still suitable at low concentrations (Zubairu \& Gana, 2014).

Thus far, limited work available regarding converting food waste charcoal to a charcoal briquette. The carbonisation of food waste using microwave technique is relatively a new knowledge to explore, hence, its final briquetting formulation. This work investigated briquetting of food waste charcoal using starch and carboxymethylcellulose (CMC) as binder. The effect of binder type and its ratio on the chemical and physical characteristics is investigated so as to have an insight of its behaviour. It is hoped that the outcome from this research could assist researcher in the effort to provide alternative to reduce the amount of food waste sent to landfilling by converting it to useful product such as charcoal briquette, which can be used for the purpose of barbeque fuel and other solid fuel application such as in a boiler.

\section{Materials and Methods}

\subsection{Sample collection and preparation}

Food waste was collected from restaurant in Seksyen 7, Shah Alam. It was collected and kept in a sealed plastic bag to reduce contamination of microorganisms in the food waste. Time of collection was about 3 days to prevent the waste from being rotten which may affect the experimental result of this research. Food waste consist of vegetables, rice, egg, fish, and chicken meat. The proportion of the food waste were $1 / 3$ of rice, $1 / 3$ of vegetables, and $1 / 3$ of meat/egg/fish.

\subsection{Binder for briquette}

A binder is used to ensure strong structure of charcoal briquette produced by increasing charcoal adhesion. Binders used for briquetting food waste char are starch (potato based) and carboxymethyl cellulose (CMC). Starch is a well-known binder in charcoal briquette industry while CMC is a new potential binder to be tested for this application. Percent of each binder are 5, 10, and 15\% to the food waste charcoal. The effect of different binder and blending ratio on the chemical and physical properties of charcoal briquette was investigated.

\subsection{Carbonisation}

Food waste sample was carbonised using microwave irradiation pyrolysis technique (Fig.1). A domestic microwave oven model Panasonic (NN-SV30) of 1kW, 2.45 
$\mathrm{GHz}$ was used and modified to fit a quartz reactor in the system. The reactor consists of $1 \mathrm{~L}$ vessel of ID $13 \mathrm{~cm}$ and height of $15 \mathrm{~cm}$, and a lid to which two openings were made to allow the inlet-outlet flow of nitrogen gas. For the production of food waste charcoal, the food wastes samples of approximately $200 \mathrm{~g}$ were used for pyrolysis operated at microwave power of $1000 \mathrm{~W}$ for an exposure time of 30 minutes. The system is firstly purged with nitrogen gas for 10 minutes, to ensure inert condition, and was set to 100 $\mathrm{ml} / \mathrm{min}$ upon pyrolysis. The collected solid product (charcoal) was measured and kept in a sealed bottle after it was ground to fine powder $(\sim 250 \mu \mathrm{m})$. Fig. 2 shows the food waste sample placement in the quartz reactor

\subsection{Mixing}

The char powder was mixed with different type of binder and blending ratio to improve adhesion of the char powder prior to briquetting. Initially, the binder will be dry mix with food waste charcoal according to their blending ratio. Next, about 50 wt.\% water/char was added to the sample and stirred homogenously. Percentage binder used in the mixture are 5, 10, and 15\%. Three briquettes for each binder type and composition were prepared for further analysis. Table 1 shows the samples notation according to the type of binder and blending ratio (S2-S7), with one sample (S1) of pure food waste charcoal as a blank sample.

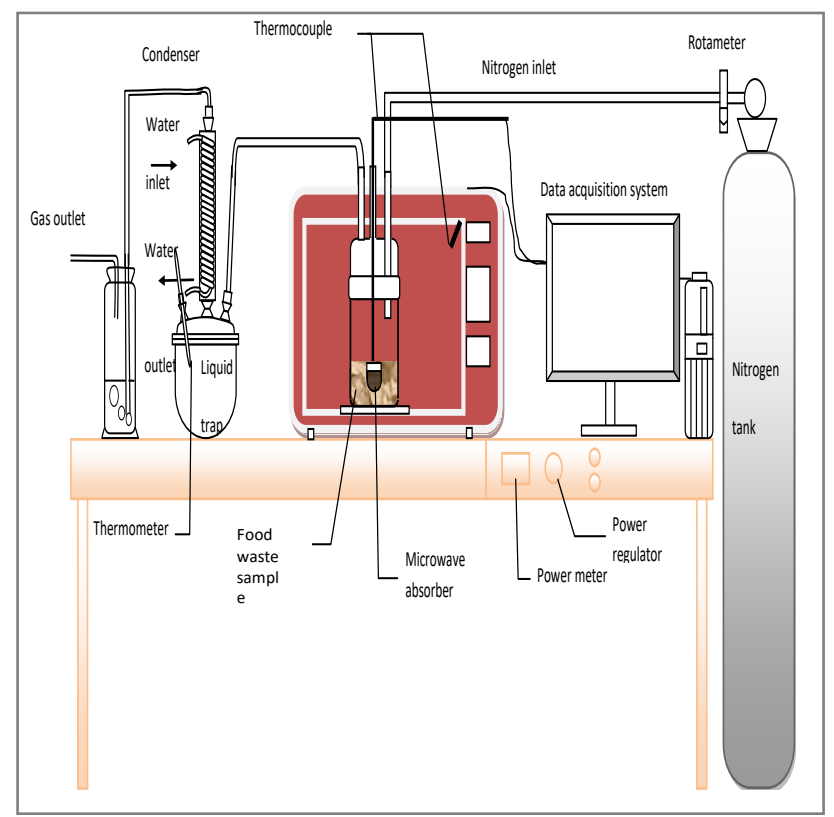

Fig. 1 Experimental setup for microwave pyrolysis process

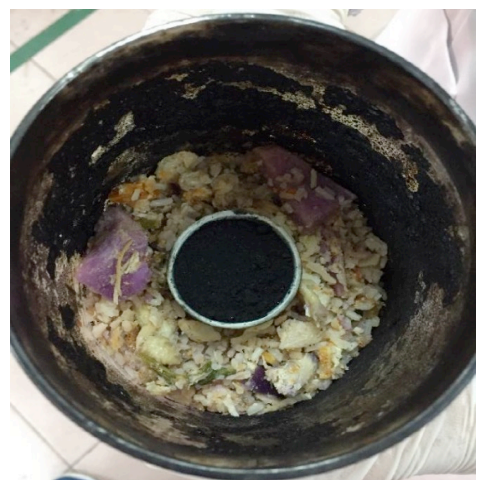

Fig. 2 Raw food waste prior to carbonisation

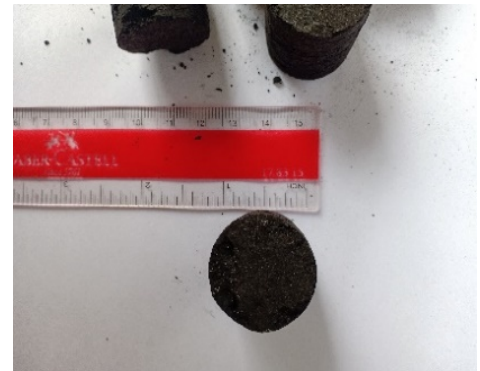

(a)

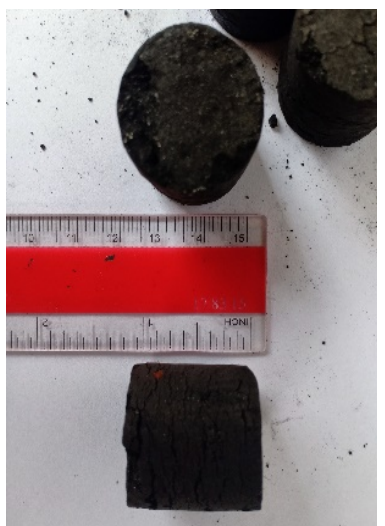

(b)

Fig. 3 (a) Sample briquette diameter, and (b) sample briquette length

\subsection{Briquetting Process}

All mixed char samples were briquetted using a 20-tonne load compression machine with punch and die method of cylindrical shape ( $25 \mathrm{~mm}$ ID $\times 25 \mathrm{~mm}$ height), as shown in Fig. 3 . The resulting briquettes were then dried in an oven at $105{ }^{\circ} \mathrm{C}$ for a duration of 2 hours.

\subsection{Chemical Tests}

A series of tests were performed to determine the calorific value, proximate and ultimate analyses of the prepared samples. Calorific value was determined according to the standard ASTM D 2015-96, using Ika-works C5000 calorimeter. Proximate analysis of the sample was performed in accordance to (ASTM D 5142-02a) using a thermo balance (TGA/ SDRA51e) manufactured by Mettler Toledo. The sample was subjected to a dynamic temperature-heating program from 25 to $950{ }^{\circ} \mathrm{C}$, at heating rate of $20{ }^{\circ} \mathrm{C} / \mathrm{min}$ under nitrogen atmosphere, with a constant flow rate of $100 \mathrm{ml} / \mathrm{min}$. Upon completion, the sample was burned using purified air at a constant flow rate of $100 \mathrm{ml} / \mathrm{min}$ to a temperature of $1100{ }^{\circ} \mathrm{C}$ at the same heating rate. As for ultimate analysis, it was performed in accordance to ASTM D 5373-02 using Thermo Finnigan Flashed 1112 analyser in order to identify the elements present in the samples.

Combustion properties of the samples were also performed using TGA. The samples were also subjected to a dynamic temperature-heating program to ramp the temperature from ambient to $1100{ }^{\circ} \mathrm{C}$, at heating rate of $10{ }^{\circ} \mathrm{C} / \mathrm{min}$, under oxidation condition using purified air $(100 \mathrm{ml} / \mathrm{min})$. The combustion properties such as ignition, peak, and burnout temperatures, were recorded. 
Citation: Idris, S.S., Zailan, M.I., Azron, N., Rahman, N.A. (2021) Sustainable green charcoal briquette from food waste via microwave pyrolysis technique: Influence of type and concentration of binders on chemical and physical characteristics. Int. Journal of Renewable Energy Development, 10(3), 425-433, doi: 10.14710/ijred.2021.33101

$\mathrm{P}$ a g e $\mid 428$

Table 1

Sample Notation for different type of binders and concentrations

\begin{tabular}{lccc}
\hline Raw material & $\begin{array}{c}\text { Type of } \\
\text { binder }\end{array}$ & $\begin{array}{c}\text { Percentage } \\
\text { of binder (\%) }\end{array}$ & $\begin{array}{c}\text { Sample } \\
\text { Notation }\end{array}$ \\
\hline $\begin{array}{l}\text { Raw Food } \\
\text { Waste }\end{array}$ & - & - & $\mathrm{S} 0$ \\
& - & - & $\mathrm{S} 1$ \\
Food waste & $\mathrm{CMC}$ & 5 & $\mathrm{~S} 2$ \\
charcoal & & 10 & $\mathrm{~S} 3$ \\
(FWC) & & 5 & $\mathrm{~S} 4$ \\
& Starch & 10 & $\mathrm{~S} 5$ \\
& & 15 & $\mathrm{~S} 6$ \\
$\begin{array}{l}\text { Commercial } \\
\text { Charcoal }\end{array}$ & - & - & $\mathrm{S} 7$ \\
\hline
\end{tabular}

\subsection{Physical Tests}

A series of tests were carried out to determine the effect of different type of binder material and its percentage on moisture content, compressive strength, and impact resistance of the samples. Moisture content for all samples were analysed from the proximate analysis using thermogravimetric analyser (TGA). Compressive strength of briquette was tested using universal tensile testing machine according to standard testing method. A charcoal briquette was put onto the provided space for sample of the briquette and increasing load is applied at a constant rate, until the sample cracks or breaks. It is advisable to put the charcoal briquette in its weakest orientation so that the accuracy of this test can be achieved. Standard charcoal briquette in market required a minimum value of $350 \mathrm{kPa}$ for compressive strength. Drop shatter test technique was used to measure the sustainability of charcoal briquette shape towards repeated impact from handling and during transportation. The test started by determining weight of every briquette using weighing balance. Each sample was dropped repeatedly (2 times) from a height of two (2) metres onto a concrete floor. The largest piece of the briquette was then measured. The shattering index of briquette was determined using equation based on ASTM D440-07 (ASTM 2012).

\section{Results and discussion}

\subsection{Production of food waste biochar}

As the focus of the experimentation is on the biochar production, only biochar (solid fraction) from the microwave pyrolysis operation is reported. Table 2 shows the yield of solid char from the microwave assisted pyrolysis of food wastes at different power and radiation time. This preliminary run showed that the pyrolysis of food waste cannot be achieved at power level of $300 \mathrm{~W}$ for operation up to 60 minutes. The food waste samples showed changes in physical appearance only upon operating at $600 \mathrm{~W}$ and $1000 \mathrm{~W}$. Pyrolysis of food waste at $600 \mathrm{~W}$ (30 minutes) and $1000 \mathrm{~W}$ (20 and 25 minutes) were not able to cause a total transformation of the food waste into biochar. At this condition the sample is not fully pyrolysed i.e. the sample is still brownish and smelly solid product. A fully pyrolysed biochar depicts a blackish light, and porous material, without any foody smell.

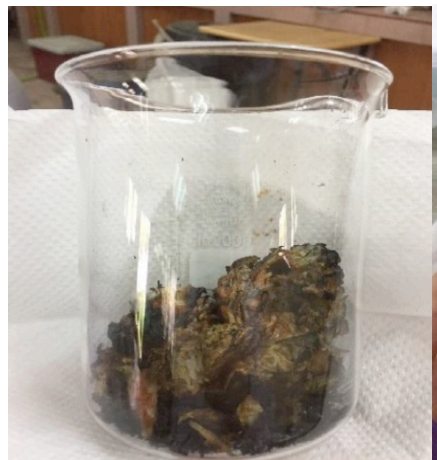

(a)

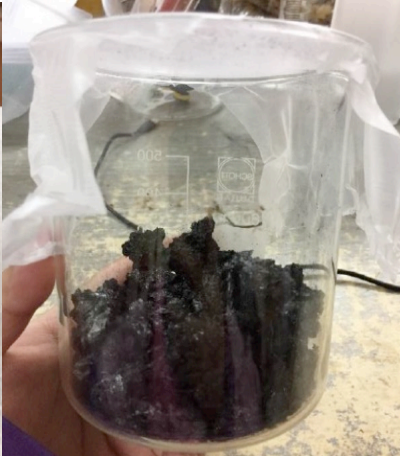

(b)
Fig. 4 (a) Sample not being pyrolysed fully, and (b) fully pyrolysed sample.

Table 2

Formation of solid char from microwave pyrolysis of food waste

\begin{tabular}{cccc}
$\begin{array}{c}\text { Power } \\
\text { (W) }\end{array}$ & $\begin{array}{c}\text { Radiation } \\
\text { Time } \\
\text { (min) }\end{array}$ & $\begin{array}{c}\text { Char } \\
\text { Yield } \\
\text { (\%) }\end{array}$ & $\begin{array}{c}\text { Remark/Observation } \\
\text { on physical } \\
\text { appearance of } \\
\text { sample }\end{array}$ \\
\hline 600 & 30 & - & Not fully pyrolysed \\
600 & 40 & 8.60 & Fully pyrolysed \\
1000 & 20 & - & Not fully pyrolysed \\
1000 & 25 & - & Not fully pyrolysed \\
1000 & 30 & 12.16 & Fully pyrolysed \\
1000 & 40 & 7.82 & Fully pyrolysed \\
\hline
\end{tabular}

The char yield is then defined as the yield of solid product upon total transformation of the feedstock to biochar. Fig. 4 shows the physical appearance of the food waste after conversion using microwave pyrolysis.

The fully pyrolysed final product (biochar) was observed when the pyrolysis was carried out at $600 \mathrm{~W}$ (40 minutes) with a yield of $8.6 \mathrm{wt} . \%$; and at $1000 \mathrm{~W}$ for a duration of 30 minutes, having a char yield of 12.16 wt.\%. Increasing pyrolysis up to 40 minutes reduces the char yield $(\sim 7.82 \%)$. This finding is similar with previous research done by Januri et al.(2016). The final product is not turning to biochar fully, when the radiation time and microwave power is not sufficient to induce the pyrolysis process. According to Januri et al. (2016), optimum condition for microwave pyrolysis of food waste wasm 1000 $\mathrm{W}$ and 30 minutes of radiation time. According to Menéndez et al. (1999) operating the microwave in this manner may not be an efficient way as the volume of the sample loaded is much smaller relative to the volume of cavity. Hence, for efficient operation, suitable mass of samples and operating time has to be considered. Thus, based on the optimum condition ( $1000 \mathrm{~W}$ and 30 minutes), the biochar is reproduced for briquetting and further testing.

\subsection{Chemical Characterisation}

\subsubsection{Proximate \& Ultimate Analysis}

Chemical characteristic of food waste charcoal briquette is shown in Table 3. The raw food waste sample contained high moisture and upon microwave assisted pyrolysis at $1000 \mathrm{~W}$ for 30 minutes, its moisture content was reduced 
tremendously. The food waste charcoal, contains considerable amount of volatile matter (ca. $39 \mathrm{wt} . \%$ ) with fixed carbon of $35 \mathrm{wt} . \%$. Commercial charcoal showed high fixed carbon and its volatile matter present of about 16 wt.\%. The volatile matter content of the charcoal briquette is considerably high as compared to the commercial charcoal. The high content of ash could be attributed by the variation of food wastes which has bones/shell that is well known to contain high inorganic materials. The highest fixed carbon for FWC+ starch is at $10 \%$ starch (ca. 56.2 wt.\%), whereas FWC+CMC showed rather low fixed carbon content $(\sim 38 \mathrm{wt} . \%)$. The low value of fixed carbon produced when using the CMC can be caused by the presence of alkynes group $-\mathrm{C} \equiv \mathrm{C}-$-), the stronger carbon to carbon bond in the alkynes group can generally results in incomplete combustion when the compounds were burnt (Timberlake, 2018).

From the elemental analysis, it can be seen that the charcoal materials contained high carbon content. The carbon content for raw food waste charcoal (46\%) was higher than that of the commercial charcoal (42\%). Similar result was recorded by the food waste char obtained from microwave assisted pyrolysis process carried on by Januri et al. (2016).

\subsubsection{Calorific Analysis}

Fig. 5 shows the effect of binder percentage and binder type on energy content of food waste charcoal briquette in comparison to the raw food waste charcoal and commercial charcoal (of palm kernel shell origin). The energy content of the raw food waste charcoal briquette (ca. 23.27 MJ/kg) is comparable to that of commercial charcoal (ca. $22.83 \mathrm{MJ} / \mathrm{kg}$ ), and the highest among other charcoal briquette formulation. This indicates food waste has the capacity as sustainable source for a quality briquette charcoal as its charcoal has calorific value is between 24.5-35 MJ/kg - a range for solid fuel in domestic and commercial application (Kurkova et al., 2003). Accordingly, Biagini et al. (2002) highlighted that a calorific value of over $20 \mathrm{MJ} / \mathrm{kg}$ is required in ensuring auto thermal combustion of a solid fuel.

Addition of binders in the food waste charcoal briquette is required as raw food waste charcoal briquette does not have strong physical structure and the binder improves cohesion forces between particles. Cohesion forces between particles makes the briquette appearances stronger (Zanella et al., 2017). The addition of binders in the charcoal mix reduces the energy content of the charcoal briquette. However, the amount of reduction is not significant.

Apparently, CMC as binder reduced the calorific value of about $3 \mathrm{MJ} / \mathrm{kg}$, in comparison to the raw food waste charcoal briquette. Unlike starch which only showed only about $1 \mathrm{MJ} / \mathrm{kg}$ reduction as compared to the raw food waste charcoal. In terms of binder, both binders showed decreasing in calorific value as percentage of binder increased. Similar behaviour was reported by Zanella et al. (2016) in their work on charcoal briquetting of orange bagasse using corn starch.

Nevertheless, the heating values of each sample was close with commercial charcoal. By comparing CMC and starch, starch can be classified as the best binder for food waste since it has higher calorific value than CMC. Unfortunately, the trend was contradict with research done by Zubairu et al. (2014) which obtained higher calorific value of corn cob charcoal with increasing binder (tapioca starch) in the briquette charcoal. Olugbade et al. (2019) highlighted in his review that the energy content of briquettes typically influenced by the addition of binders particularly if the fine and large particle size of the binder which improve the interparticle bonding. In addition, the compacting pressure also affected the energy content of the fuel briquette, in which in this current research it was set as constant.

Table 3

Chemical properties of raw food waste, food waste charcoal blends, and commercial charcoal.

\begin{tabular}{|c|c|c|c|c|c|c|c|c|c|c|c|c|c|c|}
\hline \multirow{2}{*}{\multicolumn{2}{|c|}{ Sample Name }} & \multirow{2}{*}{$\begin{array}{l}\text { Sample } \\
\text { Notation }\end{array}$} & \multicolumn{4}{|c|}{ Proximate Analysis ${ }^{\text {ad }}$ (wt.\%) } & \multicolumn{5}{|c|}{ Ultimate Analysis $^{\text {ad }}$ (wt.\%) } & \multicolumn{3}{|c|}{$\begin{array}{c}\text { Combustion } \\
\text { Characteristic } \\
\text { Temperatures }\left({ }^{\circ} \mathrm{C}\right)\end{array}$} \\
\hline & & & $\begin{array}{r}\text { Moisture } \\
\text { Content }\end{array}$ & $\begin{array}{l}\text { Volatile } \\
\text { Matter }\end{array}$ & $\begin{array}{l}\text { Fixed } \\
\text { Carbon }\end{array}$ & Ash & Carbon & Hydrogen & Nitrogen & Sulphur & 0xygen & Ignition & Peak & Burnout \\
\hline \multicolumn{2}{|c|}{$\begin{array}{l}\text { Raw Food Waste } \\
\text { (before MWAP) }\end{array}$} & S0 & 82.0 & 14.3 & 1.5 & 2.2 & - & - & - & $\cdot$ & - & - & & - \\
\hline \multicolumn{2}{|c|}{$\begin{array}{l}\text { Food Waste Charcoal } \\
\text { (FWC) }\end{array}$} & S1 & 5.6 & 45.5 & 36.5 & 12.4 & 45.6 & 7.7 & 5.5 & 0.0 & 41.2 & 222.4 & 554.9 & 646.6 \\
\hline \multirow{3}{*}{$\mathrm{FWC}+\mathrm{CMC}$} & $5 \%$ & S2 & 8.9 & 43.2 & 38.4 & 9.5 & 60.8 & 9.5 & 6.1 & 0.0 & 23.6 & 242.9 & 476.9 & 604.3 \\
\hline & $10 \%$ & S3 & 6.2 & 41.0 & 38.1 & 14.7 & 52.4 & 9.4 & 6.0 & 0.0 & 32.3 & 248.9 & 485.8 & 603.0 \\
\hline & $15 \%$ & S4 & 9.2 & 38.7 & 37.9 & 14.3 & 50.1 & 9.2 & 6.1 & 0.0 & 34.6 & 247.0 & 411.0 & 586.6 \\
\hline \multirow{3}{*}{ FWC+Starch } & $5 \%$ & S5 & 6.8 & 37.4 & 48.5 & 7.3 & 51.9 & 9.2 & 6.4 & 0.0 & 32.5 & 247.0 & 543.9 & 620.1 \\
\hline & $10 \%$ & $\mathrm{~S} 6$ & 6.8 & 29.1 & 56.2 & 7.8 & 51.6 & 9.3 & 6.5 & 0.0 & 32.7 & 245.4 & 553.2 & 653.5 \\
\hline & $15 \%$ & S7 & 5.7 & 30.1 & 55.4 & 8.8 & 54.4 & 9.2 & 6.4 & 0.0 & 30.1 & 242.5 & 543.0 & 626.1 \\
\hline \multicolumn{2}{|c|}{ Commercial Charcoal } & S8 & 7.1 & 15.8 & 54.1 & 22.9 & 42.3 & 4.6 & 3.4 & 0.0 & 49.8 & 251.3 & 451.7 & 587.1 \\
\hline
\end{tabular}


Citation: Idris, S.S., Zailan, M.I., Azron, N., Rahman, N.A. (2021) Sustainable green charcoal briquette from food waste via microwave pyrolysis technique: Influence of type and concentration of binders on chemical and physical characteristics. Int. Journal of Renewable Energy Development, 10(3), 425-433, doi: 10.14710/ijred.2021.33101 $\mathrm{P}$ a g e $\mid 430$

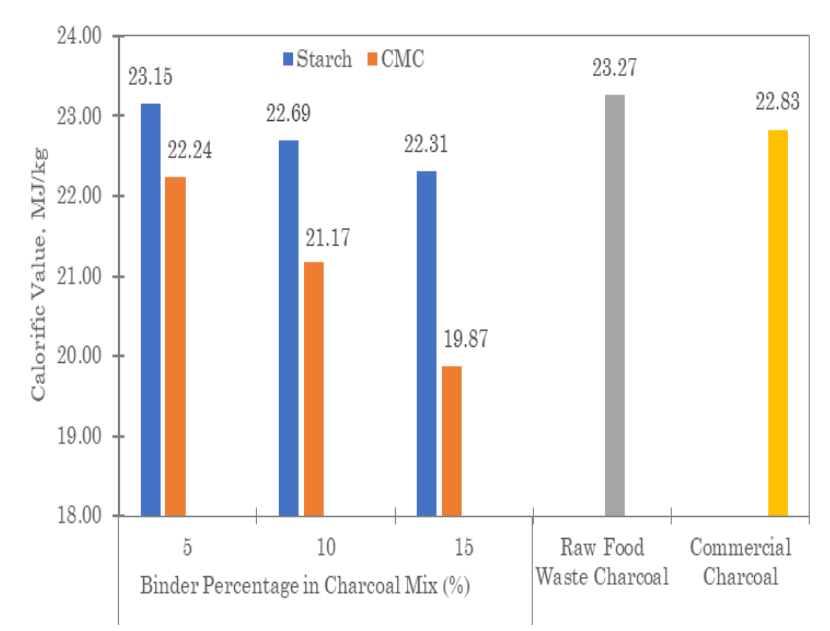

Fig. 5 Calorific value of each sample

Further investigation shall be carried out to justify this behaviour. According to Zanella et al. (2017), various substance can be a binder as long as the materials do not pose negative effect on energy characteristic of charcoal briquette, either decreasing calorific value or adding volume of volatile and ash content. Therefore, in this aspect, both the binders (CMC and starch) are not an ideal binder for food waste charcoal briquette because of reducing energy content of briquette. Nevertheless, subsequent physical tests shall testify the overall potential of these binders.

\subsubsection{Combustion Characteristics.}

Result of TGA analysis of the briquettes during combustion at $10{ }^{\circ} \mathrm{C} / \mathrm{min}$ is shown in Fig. 6. The thermograms represented for the thermal decomposition of food waste with binders of various blends for heating rate at $10^{\circ} \mathrm{C} / \mathrm{min}$. Each of the food waste to binder blends shows a distinctive DTG evolution profiles. The evolution profile (DTG) of raw food waste charcoal (FWC) and commercial charcoal, shown in Fig. 3(a) showed 4 major evolution during combustion. The first regime (I) corresponds to moisture release in the fuels $\left(50-150^{\circ} \mathrm{C}\right)$, while the second regime (II) $\left(150-400{ }^{\circ} \mathrm{C}\right)$ indicates the oxidative pyrolysis region. Peaks between 400 to $700^{\circ} \mathrm{C}$ (regime III) refers to char combustion region of solid fuels, and lastly (regime IV) between 700 to $900^{\circ} \mathrm{C}$ refers to inorganic degradation of the sample. It can be seen that the food waste charcoal contains considerable amount of reactive volatile matter. As compared to that of commercial charcoal. It is anticipated that, the food waste charcoal could give off smoke during combustion when this volatile is present in the charcoal. This could be due to the degradation of lignocellulosic material that present in the food waste charcoal that has not decomposed completely in the earlier process. The char combustion region (III) of food waste charcoal proceeded a slow (initially) followed by high reactivity of char combustion process as compared to the commercial charcoal. Ignition temperature determines how easily a particular fuel ignited and is determined by the temperature at which a sudden decrease in weight loss on the DTG curve after moisture loss regime Idris et al. (2012).
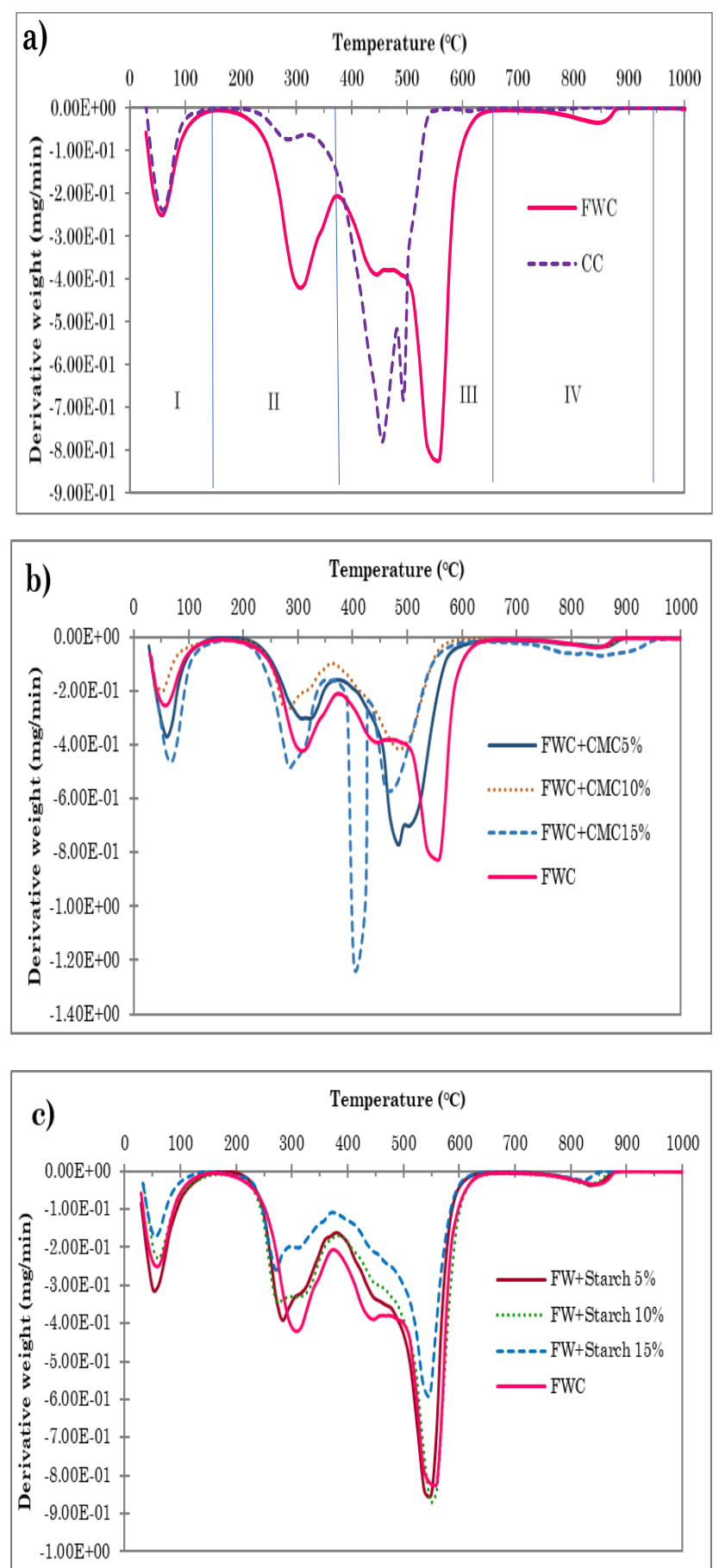

Fig. 6 DTG curves of (a) food waste charcoal and commercial charcoal, (b) food waste charcoal/CMC, and (c) food waste/starch for various ratios during combustion at a heating rate of 10 ${ }^{\circ} \mathrm{C} / \mathrm{min}$.

The ignition temperature of food waste charcoal $\left(222.4^{\circ} \mathrm{C}\right)$ is lower than that of the commercial charcoal $\left(251.3^{\circ} \mathrm{C}\right)$. In terms of burnout temperature, it is referring to the final temperature where no further mass losses during the process, with its corresponding time known as burning time, which is the time interval of the dried fuel started to lose weight until the end of combustion where the weight stabilises (Idris et al., 2012). Commercial charcoal completes the process sooner at temperature 
around $550^{\circ} \mathrm{C}$ as compared to food waste charcoal which can require longer combustion time and higher temperature up to $620^{\circ} \mathrm{C}$ (for char combustion). The degradation of inorganic materials in food waste charcoal (indicated by high ash content) is evident as the final peak showing the degradation region of inorganic degradation.

Addition of binders had increased the ignition temperature in comparison to the raw food waste charcoal. However, its value is still lower than that of commercial charcoal. The combustion characteristic of the food waste charcoal briquettes proceeded in four main regimes as its raw counterpart. The presence of binders aids the char burnout process. This is evident from the value of burnout temperatures (see Table 2), which are lower than the raw food waste charcoal. It can be seen that the peak height of char combustion regime (II) of fuel briquette having starch as the binder is higher as compared to that of having CMC as the binder.

Higher peak height indicative of high reactivity of the fuel during char combustion regime. With CMC as a binder, the briquette losses its masses sooner as indicated by the peak temperature as compared to the raw food waste. Similar behaviour was reported by Liang et al. (2019) using CMC as binder for hydro char palletisation. As for the FWC+starch, the addition of starch alters the char combustion reactivity.

From Fig. 3(b), FWC+CMC, the high percentage of CMC (15\%) showed degradation of inorganic material to end at much higher temperature due to the degradation of CMC, which also has high inorganic content in it. There is no clear trend of how the binder affects the reactivity, however from Table 3 it is obvious that the high amount of CMC added to the briquette reduces the char combustion burnout temperature. As for FWC+Starch, higher percentage of starch showed obvious reduction in the reactivity (indicated by the DTG value). The final char combustion temperature has not showed significant temperature change at different composition in comparison to the food waste charcoal and commercial charcoal. Similar observation has been reported by Liang et al. (2019) during combustion tobacco stem hydrochar pellets with different binders (i.e. inorganic and organic binders).

It can be seen that combustion characteristic of the FWC briquettes had shown different behaviour. Ideally, binders that provide high reactivity and longer char burn out time (indicated by higher temperature) is of desirable. For that matter, it can be concluded that briquette with $10 \%$ starch performs better as compared to other mixture and binders. The inorganic degradation profile is important, as it gives an indication on the suitability of employing such a briquette in the combustion furnace, which shows that operation at high temperature will result in melting of this samples which later caused fouling/slagging in the furnace which will then reduce the heat transfer efficiency.

\subsection{Characterisation of Physical Properties}

\subsubsection{Moisture content}

Moisture content of the briquetted samples, raw food waste charcoal and commercial charcoal is tabulated in Table 4. Five percent of starch in the briquette has the lowest moisture content among the samples, while the highest moisture content is recorded for CMC at $15 \%$ conc. It appears that there is no specific trend between the two type of binders regardless of its concentration on the moisture content. Nevertheless, they are well below the ideal range of moisture content as a good quality briquette (5-10 wt.\% moisture content) (Pallavi et al., 2013). In comparison to the commercial charcoal, food waste has shown potential as a feedstock to produce briquette charcoal and that both binders are suitable for this application.

\subsubsection{Compressive strength.}

Fig. 4 depicts the compressive strength of the briquetted and blank samples. The compressive strength of the briquette increases as the percentage of binder increases. Among the two binders, CMC has improved the strength almost double as compared to that of starch. Unlike CMC, the addition of starch has not improved the compressive strength significantly. Comparatively, the raw food waste charcoal recorded the lowest compressive strength (ca. $0.215 \mathrm{MPa}$ ), while the commercial charcoal has shown the highest value of $0.975 \mathrm{MPa}$. This implies that, for the food waste charcoal compression strength is improved with the addition to binder as it provides better adhesion between charcoal particles. From this test, it can be seen that $15 \%$ addition of CMC to the food waste charcoal, could achieve a compressive strength that is similar to the commercial charcoal. However, higher percentage of binder in for the briquetting, implies to increasing operating cost. Thus, the best mixture has to take other important properties into account. The compressive strength implies the ability of the briquetted materials to withstand any damage or breakage during transformation and storage. According to (Richards, 1990) the minimum requirement of compressive strength for a commercialized briquette of around $0.375 \mathrm{MPa}$.

The trend of the compressive stress increases with increasing percentage of binders is also reported by the research done on corn cob charcoal with starch carried out earlier by Zanella et al.,(2016). According to the data presented in Fig. 4, CMC provide greater agglomeration between particles than starch. Briquette that contains 5\% CMC has stress of $0.585 \mathrm{MPa}$. CMC makes stronger shape of briquette than starch and is able to withstand physical damages during processing, handling, and transporting. Similar finding was reported in using CMC as binder with hydro char of tobacco stem by Liang et al. (2019).

Table 4

Moisture content (wt.\%) of briquette sample

\begin{tabular}{ccc}
\hline \multirow{2}{*}{ Binder Conc. (wt.\%) } & \multicolumn{2}{c}{ Moisture Content (wt.\%) } \\
\cline { 2 - 3 } & Starch & CMC \\
\hline 5 & 6.8 & 8.9 \\
10 & 6.8 & 6.2 \\
15 & 5.7 & 9.2 \\
\hline Blank sample & \multicolumn{2}{c}{ Moisture Content (wt.\%) } \\
\hline Food Waste Charcoal & \multicolumn{2}{c}{5.6} \\
Commercial Charcoal & \multicolumn{2}{|c}{7.1} \\
\hline
\end{tabular}


Citation: Idris, S.S., Zailan, M.I., Azron, N., Rahman, N.A. (2021) Sustainable green charcoal briquette from food waste via microwave pyrolysis technique: Influence of type and concentration of binders on chemical and physical characteristics. Int. Journal of Renewable Energy Development, 10(3), 425-433, doi: 10.14710/ijred.2021.33101 $\mathrm{P}$ a g e $\mid 432$

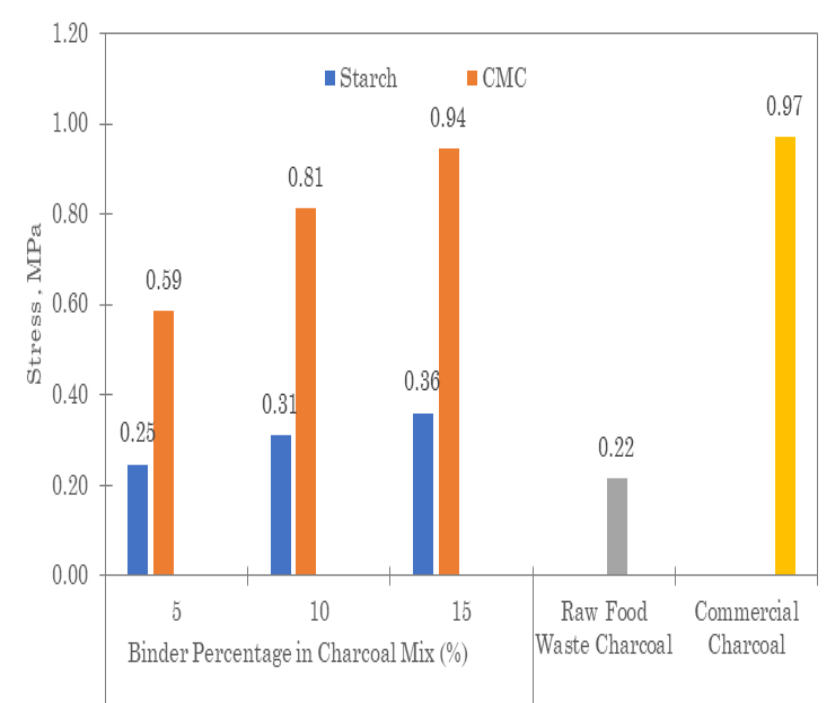

Fig. 7 Compressive strength of each sample

However, starch did not achieve the minimum value of compressive strength with the percentage binder up to $15 \%$. This could be due to the unfavourable mixing method of the charcoal with starch which can be achieved by using dry and wet mixing technique. Current research, used a dry mixing is applied where water is added after mixing of starch powder and charcoal. Zanella et al.,(2017) stated that initial mixing of binder and water provide better homogenization of them, and when combine with charcoal, the mixture reaches particle's pore.

It can be seen that, for starch to be employed as a good binder that fulfils the compression strength specification, the percentage of starch added has to be increased, however this could also translate into high cost in briquetting production. It is suggested that various type of starch has to be used to determine the suitable binders with low cost that allow better specification of charcoal briquette be achieved. Current starch used is not be suitable with food waste charcoal since many researchers used different type of starch succeed in making starch as a binder. This fact is supported by Borowski et al.(2017), Zanella et al.(2016) and Zubairu et al.(2014).

In conclusion, briquette sample with percentage of $10 \%$ CMC (S3) is the most ideal blending ratio in making a quality briquette due to strong compressive strength, cost effective and achieved requirement of commercialized briquette.

\subsubsection{Impact Resistance (Shattering Index)}

Impact resistance characteristic was a key in production of briquette in terms of handling, storage, and transporting. Based on the result obtained in Table 3 , briquette sample that mixed with $5 \%$ starch had lowest shattering index, which was $5.22 \%$. Highest value for shattering index gained from sample S4 that contain 15\% CMC in the briquette.

By comparing starch and CMC as binder, CMC had showed greater shear strength than that of starch. High shear strength stipulated that a binder had a good capability to prevent binding substance for breakaway because of some force. This statement is supported by Cahyono et al. (2017).
Table 5

Shattering index of briquette

\begin{tabular}{cccc}
\hline \multirow{2}{*}{ Sample } & \multicolumn{2}{c}{ Weight (gram) } & \\
\cline { 2 - 3 } Sh $_{\text {in }}$ (\%) \\
\hline S1 & Before & After & \\
S2 & 10.54 & 0.64 & 6.07 \\
S3 & 10.96 & 10.88 & 99.27 \\
S4 & 10.74 & 10.72 & 99.81 \\
S5 & 9.34 & 9.33 & 99.89 \\
S6 & 10.16 & 0.53 & 5.22 \\
S7 & 10.15 & 1.94 & 19.11 \\
CC & 10.43 & 2.91 & 27.90 \\
\hline
\end{tabular}

When comparing briquette sample S3 and S4 with commercial charcoal, it was proven that S3 and S4 sample had better value of shattering index than commercial charcoal. This proved that FWC briquette sample with addition of CMC has potential to become a good quality briquette in the future. Thus, it can be concluded, as percentage binder is increased, shattering index increased, and stronger briquette will be produced.

\section{Conclusion}

The present study has demonstrated the feasibility of converting high moisture food wastes sample into useful biochar or charcoal using microwave pyrolysis technique. The process only requires 30 minutes of operation to produce high energy content of charcoal ( ca. $23 \mathrm{MJ} / \mathrm{kg}$ ) which is comparable to energy content of commercial charcoal $22.83 \mathrm{MJ} / \mathrm{kg}$. A quality charcoal briquette takes into considerations of chemical and physical properties, which has been discussed in this work. From the chemical properties point of view, calorific value and combustion characteristic play an important role. A high calorific value with low ignition and long burnout time is highly desirable. In this case $\mathrm{FWC}+10 \%$ Starch meets the purpose. This work has investigated the charcoal briquette mixture for the physical test including moisture content, compressive strength, and impact resistance. The ability of the charcoal briquette to withstand impact that can make damage to its shape and structure has been carried out. For this matter, charcoal briquette with $10 \%$ of CMC met the desired specification of a quality briquette due to its strongest physical strength.

It appears that both binders have shown opposite characteristics. However, for a good briquette with quality physical tests, the charcoal briquette with $10 \%$ CMC can be considered as a good formulation, though it meets minimum calorific value requirement. For future work, it is proposed that optimisation statistical technique being employed for selecting the best binder that meets the requirement. In addition, the impact of the combustion of 
the charcoal on environment shall be assessed towards sustainable environmental condition.

The study indeed provide insight on the use of microwave pyrolysis technique to convert food wastes to useful solid fuel, i.e. charcoal briquette for the purpose of combustion. This study is important as it provides alternative solution to food wastes disposal as alternative sustainable energy source.

\section{Acknowledgments}

Authors would like to thank the financial support by the, Universiti Teknologi MARA (UiTM) through MyRA Grant (600-RMC/MYRA 5/3/LESTARI (016/2020) and research facilities.

\section{References}

Antunes, E., Jacob, M. V., Brodie, G., \& Schneider, P. A. (2018). Microwave pyrolysis of sewage biosolids: Dielectric properties, microwave susceptor role and its impact on biochar properties. Journal of Analytical and Applied Pyrolysis, 129(October 2017), 93-100. https://doi.org/10.1016/j.jaap.2017.11.023

Biagini, E., Lippi, F., Petarca, L., \& Tognotti, L. (2002). Devolatilization rate of biomasses and coal-biomass blends: An experimental investigation. Fuel, 81(8), 1041-1050. https://doi.org/10.1016/S0016-2361(01)00204-6

Borowski, G., Stẹpniewski, W., \& Wójcik-Oliveira, K. (2017). Effect of starch binder on charcoal briquette properties. International Agrophysics, 31(4), 571-574. https://doi.org/10.1515/intag-2016-0077

Bu, Q., Morgan, H. M., Liang, J., Lei, H., \& Ruan, R. (2016). Catalytic Microwave Pyrolysis of Lignocellulosic Biomass for Fuels and Chemicals. 1, 69-123. https://doi.org/10.1016/bs.aibe.2016.09.002

Cahyono, R. B., Santoso, J., \& Miliati, R. (2017). Biomass Briquettes using Indonesia Durian Seeds as Binder Agent : The Effect of Binder Concentration on the Briquettes Properties. Chemical Engineering Trans, 56, 1663-1668. https://doi.org/10.3303/CET1756278

Elkhalifa, S., Al-Ansari, T., Mackey, H. R., \& McKay, G. (2019). Food waste to biochars through pyrolysis: A review. Resources, Conservation and Recycling, 144(September 2018), https://doi.org/10.1016/j.resconrec.2019.01.024

Foong, S. Y., Abdul Latiff, N. S., Liew, R. K., Yek, P. N. Y., \& Lam, S. S. (2020). Production of biochar for potential catalytic and energy applications via microwave vacuum pyrolysis conversion of cassava stem. Materials Science for Energy Technologies,

728-733. https://doi.org/10.1016/j.mset.2020.08.002

Idris, S. S., Rahman, N. A., \& Ismail, K. (2012). Combustion characteristics of Malaysian oil palm biomass, subbituminous coal and their respective blends via thermogravimetric analysis (TGA). Bioresource Technology, https://doi.org/10.1016/j.biortech.2012.07.065

Januri, Z.B., Idris, S. S., Rahman, N. A., Matali, S., Manaf, S. F. A., Rahman, A. F. A., \& Rahman, S. N. F. S. A. (2016). Solid char characterization from effect of radiation time study on microwave assisted pyrolysis of kitchen waste. Journal of Engineering Science and Technology, 11(Special Issue onsomche2015).
Januri, Zakiuddin B., Idris, S. S., Rahman, N. A., Matali, S., Manaf, S. F. A., Rahman, A. F. A., \& Rahman, S. N. F. S. A. (2016). Solid char characterization from effect of radiation time study on microwave assisted pyrolysis of kitchen waste. Journal of Engineering Science and Technology, 11(Special Issue onsomche2015), 50-62.

Kadlimatti, H. M., Raj Mohan, B., \& Saidutta, M. B. (2019). Microwave-assisted pyrolysis of food waste: optimization of fixed carbon content using response surface methodology. Biofuels, $O(0)$

$1-8$. https://doi.org/10.1080/17597269.2019.1573609

Kurkova, M., Klika, Z., Martinec, P., \& Pegrimocova, J. (2003). Composition of bituminous coal in dependence on environment and temperature of alteration. Bulletin of Geosciences, 78(1), 23-34.

Li, J., Dai, J., Liu, G., Zhang, H., Gao, Z., Fu, J., He, Y., \& Huang, Y. (2016). Biochar from microwave pyrolysis of biomass: A review. Biomass and Bioenergy, 94, 228-244. https://doi.org/10.1016/j.biombioe.2016.09.010

Liang, M., Lu, W., Lei, P., Wang, L., Wang, B., Li, B., Shen, Y., \& Zhang, K. (2019). Physical and Combustion Properties of Binder-Assisted Hydrochar Pellets from Hydrothermal Carbonization of Tobacco Stem. Waste and Biomass Valorization, 0123456789. https://doi.org/10.1007/s12649019-00848-x

Liu, H., Ma, X., Li, L., Hu, Z. F., Guo, P., \& Jiang, Y. (2014). The catalytic pyrolysis of food waste by microwave heating. Bioresource Technology, 166, 45-50. https://doi.org/10.1016/j.biortech.2014.05.020

Menéndez, J. A., Menéndez, E. M., Iglesias, M. J., García, A., \& Pis, J. J. (1999). Modification of the surface chemistry of active carbons by means of microwave-induced treatments. Carbon, 37(7), 1115-1121. https://doi.org/10.1016/S00086223(98)00302-9

Olugbade, T., Ojo, O., \& Mohammed, T. (2019). Influence of Binders on Combustion Properties of Biomass Briquettes: A Recent Review. Bioenergy Research. https://doi.org/10.1007/s12155-019-09973-w

Pallavi, H., Srikantaswamy, S., Kiran, B., Vyshnavi, D., \& Ashwin, C. (2013). Briquetting agricultural waste as an energy source. Journal of Environmental Science, Computer Science and Engineering \& Technology, 2(1), 160-172.

Richards, S. R. (1990). Physical testing of fuel briquettes. Fuel Processing Technology, 25(2), 89-100. https://doi.org/10.1016/0378-3820(90)90098-D

Sotannde, O. A. ., Oluyege, A. O. ., \& Abah, G. B. . (2010). Physical and combustion properties of charcoal briquettes from neem wood residues. International Agrophysics, 24(August 2017), 189-194.

SW Corp. (n.d.). Laporan Komposisi Sisa Pepejal. https://jpspn.kpkt.gov.my/index.php/pages/view/69

Timberlake, K. C. (2018). Chemistry: An introduction to general, organic, and biological chemistry, global edition. Pearson Education, Limited.

Zanella, K., Concentino, V. O., \& Taranto, O. P. (2017). Influence of the Type of Mixture and Concentration of Different Binders on the Mechanical Properties of " Green " Charcoal Briquettes. Chemical Engineering Transactions, 57(June), 199-204. https://doi.org/10.3303/CET1757034

Zanella, K., Gonçalves, J. L., \& Taranto, O. P. (2016). Charcoal Briquette Production Using Orange Bagasse and Corn Starch. Chemical Engineering Transactions, 49(2004), 313-318. https://doi.org/10.3303/CET1649053

Zubairu, A., \& Gana, S. A. (2014). Production and Characterization of Briquette Charcoal by Carbonization of Agro-Waste. Energy and Power, 4(2), 41-47. https://doi.org/10.5923/j.ep.20140402.03 